\title{
Teacher-Student-Relationships in Teacher Education: Exploring Three Projects of Knowledge Transfer into Action
}

\author{
Gisela Steins*, Bita Behravan \\ Institut für Psychologie, Fakultät für Bildungswissenschaften, Universität Duisburg-Essen, Essen, Germany \\ Email: *gisela.steins@uni-due.de
}

How to cite this paper: Steins, G., \& Behravan, B. (2017). Teacher-Student-Relationships in Teacher Education: Exploring Three Projects of Knowledge Transfer into Action. Psychology, 8, 746-770.

https://doi.org/10.4236/psych.2017.85048

Received: December 8, 2016

Accepted: March 28, 2017

Published: March 31, 2017

Copyright ( $) 2017$ by authors and Scientific Research Publishing Inc. This work is licensed under the Creative Commons Attribution International License (CC BY 4.0). http://creativecommons.org/licenses/by/4.0/

\begin{abstract}
How teachers are best educated is a question that has been discussed for a long time. One perspective to this debate focuses particularly on dovetailing theoretical knowledge with practice. The present research is devoted to the specific exploration of this dovetailing: Three projects are presented that allow a direct transfer of knowledge into practice. The critical knowledge in the projects focuses explicitly on creating a supportive teacher-student-relationship. In the theoretical part of this contribution, the relevance of a supportive teacherstudent-relationship is discussed according to the background of teacher students' apprenticeship of observation. The research question is if the projects deliver strategies, ways and solutions to challenge the contents of apprenticeship of observation and accordingly to transfer empirically-based knowledge into action of teachers with regard to creating a supportive teacher-studentrelationship. Project 1 refers to accompanied sponsorships between teacher students and pupils $(N=15)$, project 2 combines classroom management knowledge with teaching social learning in a class $(N=13)$ and project 3 refers to the reintegration of mentally ill students back to school $(N=10)$. Qualitative analysis of knowledge transfer grounds on self-reports of teacher students and partly observation of teacher educators. The results hint to the value of action in academic education and are discussed in relation to their effects of gaining competencies and their feasibility.
\end{abstract}

\section{Keywords}

Teacher-Student-Relationships, Theory Practice Transfer, Teacher Education, Apprenticeship of Observation

\section{Introduction}

This contribution is a reanalysis of the data we obtained in projects which pri- 
marily were designed to support adolescents. The present reanalysis focuses on the question if and how teacher students can learn evidence-based professional behavior in an academic context by dovetailing academic knowledge and concrete behavior. When we worked on the projects we did not intend to investigate the teacher students' perspectives. However, the problem how to combine knowledge with behavior was always present and the need to investigate this aspect was truly felt. In the theoretical part we describe the problem of knowledgetransfer into the context of Teacher Education and introduce the important content of teacher-student-relationship that is addressed specifically in the projects.

\section{A Peculiarity of Teacher Education: The Apprenticeship of Observation}

Most people have experienced school. They were students, have met various teachers and spent many hours of their student life talking with their classmates about teachers. Thus, they had observed models of teacher action and they have formed their own subjective opinion about these models by making social comparisons with other students. Therefore, researchers agree that school as a field of social experience, implicitly instructs how teachers behave and solve problems. For a century and a half following the founding of mass public education, the relationship between teachers and students has elicited general concern accompanied by the recognition that students and teachers have inside classrooms (Muller, 2001) which gives us the idea that behaving toward students is learned indirectly at school. One of pioneers on this matter, Lortie (1975) named this implicit education "apprenticeship of observation", (p. 61). Thus, gradually stronger than in other professions, teacher students already bring their previous socially shared experience and knowledge into their education.

A significant problem that arises here is that this observational and socially affirmed knowledge can form the basis of a rating scheme, which only allows acceptance of knowledge that is familiar with contents of the apprenticeship of observation. Thus, there is probably a conflicting concurrence between trusting experience-based models of teacher behavior and trusting evidence-based knowledge. These are two different models of education: Experience-based-models comprise imaginations about actions on the basis "That's just the way it is", because most of persons or the reference group (peers) behave like that. However, scientific evidence is lacking to explain the appropriateness of actions. Evidencebased models of actions comprise scientific knowledge about appropriateness of actions. But, even if the teacher student is willing to act according to evidencebased knowledge, it would be not always easy to do so, because researchers and educators are not consistent and partially because they had also experienced an apprenticeship of observation and are parts of a larger social context of opinions which can have a great influence on their actions. And even, if teacher students are willing to direct their own behavior according to evidence-based knowledge and decide to do what is appropriate, they probably have no idea how to imple- 
ment their knowledge into behavior because the appropriate behavior was never trained. Researchers specifically addressed these problems (e.g. Loewenberg Ball \& Forzani, 2009; Steins, Wittrock \& Haep, 2015; Steins, Haep \& Wittrock, 2015). Basically, the cold relationship of teacher and students is what they usually remember from school but if a good rapport existed, the environment for learning would have been more desirable that could have made the knowledge to be transferred more efficiently. A lot of unanticipated problems and challenges can occur inside the classroom including the student bringing their familial, behavioral, and societal problems into classroom making it hard for teachers to teach the lesson and act efficiently in the classroom. In reality the teacher is faced with a problem that seems unsolvable since the problematic students are present in class throughout the year, not being able to solve this problem could bring frustration and burn outs for the teachers that can affect the whole class.

To put it theoretically, there is a lot of evidence to state that the technical rationality model (Schön, 1983) - theory and practice are taught, learnt and applied-is a weak model concerning practice. As Lewin and Stuart (2003) note:

"In reality, this does not happen. Trainees are faced with many confusing situations which they do not know how to deal with, and they often have access to very limited support to help them solve problems. Learning to teach effectively requires that trainees integrate the insights and concepts derived from the public propositional knowledge available in colleagues with the contextual and situated knowledge of specific classrooms and pupils. This implies that the theoretical and practical elements of the curriculum should be intertwined and presented in a dialogic relationship, rather than as discrete elements." (p. 700). In the next section it will be discussed that this may be a fragile solution, too.

Lewin and Stuart noted this according to the situation of teacher-education in low-income countries. However, many studies show that not being able to implement the knowledge into action, specifically in problematic situations is global (e.g. Germany: Steins, Wittrock, \& Haep, 2015, 2016; US: Rushton, 2000; Greece: Efihimiou, 1995).

For Freire (cited in Bartlett, 2005), all learning is relational and knowledge is produced in interaction. Knowledge is not a piece of data, something immobilized, concluded, finished and something to be transferred by one who acquired it to one who still does not possess it. A teacher cannot transfer the knowledge if students are not thinking, not ready and motivated to learn, motivating the students is avital and basic step in the process of teaching and hence learning because learning is not a one way street (Bartlett, 2005). The more eager the students are to learn, the easier the knowledge is transferred and meanwhile if the students actively participate in the classroom the teachers would have to put less effort to put the specific knowledge across to students.

The long lasting effects of contents acquired by the apprenticeship of observation represent a profound knowledge-action gap, which consists of two serious unsolved problems in Teacher-Education: 1) how can evidence-based knowledge be transferred into action?, 2) what kind of knowledge is undeniably relevant for 
applying the teaching profession in a way that students are supported in their academic, social and emotional development?

The present research discusses the first problem. The second problem is not the subject of this contribution. The knowledge that is acquired by all these three projects makes a specific skill for the teachers called "the ability to create a good teacher-student rapport". First, the knowledge-action problem is discussed in further detail, then, the introduction of knowledge about creating a supportive teacher-student-relationship in Teacher Education is considered.

\section{A Peculiarity of Human Beings: Gap between Knowledge and Action}

The gap between knowledge and action affects almost all human subjects and hence all sectors of society hence, it is not only the question of teacher education. It seems that real knowledge will not necessarily be put into action. People tend to act as contextual factors and habits suggest. Own experience-based knowledge is durable and rugged and resists evidence-based knowledge, especially if the context suggests us to stay with our own experience. The process of moving from a reality frame of reference to another is so complex, because motivational, emotional, cognitive, and behavioral aspects are involved. This line of reasoning is supported by scientists of different disciplines over a considerable period of time (e.g. Hawthorne \& Stanley, 2008; Lewin \& Grabbe, 1945; Markuskaite \& Goodyear, 2017).

Lewin and Grabbe (1945) especially emphasized on the social reality, the reference group of people (peers and supervisors), which can promote a change from one framework of reality to another. According to this line of reasoning, evidence-based knowledge can be integrated in its own knowledge system only when it is accepted by the relevant peer group. Lewin and Grabbe emphasize that the persons we belong to, create a social reality, a kind of culture persons try to practice. Persons we belong to, often do not construct and unit but may represent different social realities in our lives (1945, pp. 450-451). Knowledge that is acquired at university as a teacher student may be different to that acquired as being a teacher at school because there is a different peer group in each context by which we mean other teacher students and supervisors at university and other teacher colleagues and supervisors at the school. The same person, the former teacher student and the present teacher, might be convinced about the appropriateness of conflicting action models because the reference group creates a special social reality. Thus, even if real knowledge is integrated into one's knowledge system as credible and effective, it will be implemented only if it is shared by the reference group of the action-relevant context.

Thus, it is not enough to link knowledge with practice. Philpott (2006) indicates this point using the perspective of Engeström's activity theory $(1999,2001)$. From this perspective, the segregation of school and education location as two separate systems with their own social rules becomes problematic because two different identities are developed (Teacher vs teacher student). To be able to 
transfer knowledge in action presupposes opportunities to implement knowledge appropriately. Furthermore, teacher students have to be motivated to do so and the acts must be estimated by their peer group. However, intertwining theoretical and practical elements (see the citation of Lewin \& Stuart, 2003: p. 700) guarantees no transfer of empirically based knowledge because its acceptance depends on the peer group (Lewin \& Grabbe, 1945; Philpott, 2006) and the peer groups' standards of university and school differ considerably.

Thus, the implementation of knowledge cannot happen without a solution for the problems that were addressed here. It is not surprising, that research about the success of linking knowledge with action in Teacher Education are highly inconsistent: While some researchers present positive results for their concepts of intertwining theory and practice (Sport: Irwin \& Ryan, 2013; Biology: Janssen, Westbroek, \& Doyle, 2014; Vocational-Learning: Billett, 1998; Gruber, Law, Mandl, \& Renkle, 1995), others report that standard lectures would lead to the same learning effects as simulation or other mixtures of theory and practice can do (Hoeppner, von Keyserlingk, Koerndle \& Proske, 2015; Rowell, Pope \& Sherman, 1992; Steins, Haep \& Wittrock, 2015). However, it will not be irrelevant for the transfer effect to know how concepts were implemented (Forzani, 2014; Zeichner, 1993) and usually there is no information about acceptance of knowledge by the teacher students and their peer group in these studies.

The knowledge that has been paid special attention to in this study concerns building supportive teacher-student-relationships.

Norms of teacher-students relationship suggest that it should facilitate learning but some behaviors from both sides violates this norm which shows that teacher-student relationships can't always follow the norms (Muller, 2001) such as ignoring the problematic students. Teachers have more negative attitudes and behavior toward students who have disabilities and/or students who do not perform well academically. Therefore, they show less support toward these students and might ignore or blame them (Montague \& Rinaldi, 2001, cited in Murray \& Pianta, 2007). One of the reasons that teachers ignore these students is that they invest in students whom they expect to succeed (Muller, 2002), and the behavior of ignoring the students who don't perform well makes a vicious circle that coming out it of requires a planned and serious solution like the projects that had been run by us.

\section{Teacher-Student-Relationship}

\subsection{Importance of Knowledge about the Social Dimension of Teaching}

How something is made, is at least as important as what is done (Evertson \& Weinstein, 2006; Zeichner, 1993). The teacher's manner of creating the interaction with the students is addressed here, known as Teacher-Student-Relation (ship) or teacher-student-interaction. Many empirical studies report medium to strong effects of Teacher-Student-Interaction variables on different aspects of the development of students. It necessarily matters what actions teachers take, 
especially when students have to overcome difficulties (Algozzine, Ysseldyke, Christenson, \& Thurlow, 1983). Many studies suggest that the quality of the relationships that children form with their teachers has important implications for their emotional and behavioral well-being (Hughes, Cavell, \& Jackson 1999).

The relationship between teachers and students is so important that studies (Reddy, Rhodes, \& Mulhall, 2003) reported that early adolescents with increasing support levels from their teachers have higher self-esteem. Research in this area indicates that the quality of teacher-student relationships affects students' emotional and behavioral engagement in school (National Research and the Institute for Medicine, 2004, cited in Murray \& Pianta, 2007).

A lot of teachers are aware of the importance of teacher-student relationship. This knowledge comes from the direct interaction between teachers and students which have led to more positive responses of students who had had their teachers' support (Murray \& Pianta, 2007).

More recently Pianta (1999), Pianta, Hamre, and Stuhlman (2003), proposed that teacher-student relationship is an important component of a broader integrative of human development. According to their proposal, this relationship can help students to develop in different dimensions (cited in Murray \& Pinata, 2007). Regarding this perspective, teacher-student relationships are developed and maintained through a lot of components such as student background characteristics, teacher' characteristics, classroom and school characteristics as well as family, community, and broader social influences (Pianta, 1999).

\subsection{Two Relevant Dimensions of a Supportive Teacher-Student-Relationship}

There are many approaches to characterize a supportive teacher-student-relationship. At least two relevant descriptive dimensions of a supportive teacher student relationship, based on research about education in family and school, can be extracted for the sake of simplicity (1) the emotional affection that the adolescents experience (low to high) and (2) the orientation of or the requirements for the adolescents (low to high). The combination of both dimensions with a high degree seems to be optimal for the development of an adolescent considering cognitive and social-emotional skills and especially for students with emotional and social difficulties (Den Brok \& Levy, 2005; Hamre \& Pianta, 2001, 2005; Liew, Chen, \& Hughes, 2010; Reyes, Elias, Parker, \& Rosenblatt, 2013; Shechtman \& Leichtentritt, 2004; Sleeter, 2008; Skiba \& Knesting, 2001; Weinstein, Tomlinson-Clarke, \& Curran, 2004; Woolfolk Hoy \& Weinstein, 2006). Nevertheless the combination of these dimensions (much emotional support and high expectation) is not intuitive. As Woolfolk Hoy and Weinstein (2006) reported, the ability to exercise authority without being rigid, threatening or punitive contradicts imaginations of how to establish a caring relationship. But both aspects are important features of a supportive relationship as seen by students and researchers. Furthermore, the combination is complicated, because it is culturally affected by how authority and care is perceived. 
There is always a power imbalance in the classroom between the specific knowledge that is taught and this imbalance can be compensated by students participating and of course the existence of teacher-student relationship. Teachers normally hold the control in the classroom and have more power over students, students also have some power and might use their power against teachers, and this power game might create an unfriendly atmosphere in classroom, if teachers have a good relationship with student the chances of this conflict will decrease (Freire, 1973; cited in Bartlett, 2005).

Teachers and students normally communicate with each other based on their roles. This is a sociological level of communication according to Dobransky and Frymier (2004) but when they communicate as individuals their communication is on the psychological level (Dobransky \& Frymier, 2004). Research have demonstrated that when teachers and students have one to one relationships outside school, students showed better learning (Andersen, 1979; Christophel, 1990; Comstock, Rowell, \& Bowers, 1995 cited in Dobransky \& Frymier, 2004).

Pitfalls. The detailed description of a desired interaction style of teachers with their students contains many pitfalls that can cause some problems in the transfer of knowledge. To be emotionally supportive can suggest different actions for different people. In her historical analysis of the situation of female teachers in New York in the twenties Rousmaniere (1994) shows that the request to be caring and emotionally supportive is certainly gender-related and can lead to massive role conflicts in female teachers, which can limit the capacity of some teachers (see also Carli \& Eagly, 2012). Research about the care like the one by Morris and Morris (2002) show that this problem is still not solved.

There is always a problem of teachers who resist to get close to students and break the formal teacher-student relationships. Therefore, Teachers must be taught that sometimes it is better to come out of the strict role-based relationship and getting to know the students specially the problematic ones while constructive teacher-student relationships have been shown to impact affective learning which facilitates cognitive learning (Eiss, 1969).

Likewise, the second dimension of a desired interaction style is vaguely described. Giving orientation to a student and requiring performance is often operationalized by teacher's expectations. It seems to be evident that teachers should have high expectations toward their students (Meissel \& Rubie-Davies, 2016). Teachers' expectations show significant effects on students' educational success (Becker, 2013). Peterson, Rubie-Davies, Osborne and Sibley (2016) note:

"These findings suggested that teachers need to be explicit about having high expectations for achievement in all subject areas and for all students. Taking such an approach may help buffer students from any nonverbal cues that may suggest the teachers not to have high achievement expectations." (p. 137)

But it is one aspect to understand why it is important to implement high expectations for real students. At least it is not clear if there is any limit for the amount of expectation and if so, where it shall be. In a specific classroom, teachers have no clear guidelines about the appropriateness of their expectations and 
probably will follow the school policy—the social context (Lewin \& Grabbe, 1945; Philpott, 2006).

\subsection{Confusing Terms Associated with Supportive Teacher-Student-Relatiopnship}

Furthermore, the dimensions of supportive teacher-student-relationship are associated with confusing terms. Two core concepts exemplify this fact: empathy and reflection. These concepts are partly problematized as examples to show that it is difficult for a teacher student to gain real knowledge about creating a supportive teacher-student-relationship.

Empathy seems to be important for a supportive teacher-student-relationship. It is always called as an important component for successful teaching (Cornelius-White, 2007; Hattie, 2009). Researchers have noted that students who have their teachers' empathy are more motivated and get better marks than the ones who don't (McAllister, 1999). What does empathy concretely mean in terms of behavior toward a student? Rightly so, empathy was criticized as a morally loaded concept (Steins, 2000), under which also false empathy (Warren \& Hotchkins, 2015) can be hidden. At least, empathy is a controversially defined term that is not suitable to use without further context in teacher education.

Likewise it is difficult for teacher students to decode the meaning of the term reflection. Dewey (1993) considered reflection to be a special form of problem solving, which is a careful ordering of ideas that link each of them to their predecessors, this "reflection" can also be used in developing teacher-student relationships. These ideas can be used as an effective cognitive process involves underlying knowledge and beliefs. However, the research about the function of reflection is diverse and even has a specifically critical position such as the study of Garcia and Lewis (2014), who understand the primacy of reflection as a hindrance to the work of a teacher. It remains problematic because in various uses of the term reflection it is often not very clear, what method of reflection is meant (Hebert, 2015) and which level of reflection is discussed (Larrivee, 2006).

The listed term difficulties can only superficially solve a few problems since it is not the intention of the contribution. We rather want to point out that we are aware of these inaccuracies and problems and see them as one whole problem of knowledge acquisition about important aspects of creating a supportive teacher-student-relationship. These inaccuracies are probably one cause for the fact that during the continuous teaching period, emotional support for students is neglected by teachers in favor of classroom organization (Malmberg, Hagger, Burn, Mutton, \& Colls, 2010). Classroom organization is associated with more concrete operations.

\section{Present Research}

According to the background of these reflections, three knowledge-transfer-toaction projects in Teacher Education were created. All of them focus on the transfer of knowledge about personal relationships, which means the importance 
of implementation of modeling, support, caring, expectations and self-regulation into practical behavior. To explore what is happening with teacher students while learning how to practice this knowledge is the central focus of the present research.

The common focus of the three projects is to design a supportive teacherstudent-relationship pattern. The challenge of the three projects is to support teacher students to see the contradictions between the scientific understanding of a desired teacher-student-relationship and their own experience, common sense and their own values. Thus, the contracts of the projects can tackle the above mentioned problems in teacher education, to implement relevant knowledge in an individual action repertoire.

The background and progress of the projects is quite diverse. The effects on the students are already, to a high extent, researched and published. So far, the teacher students' perspectives were neglected. Thus, the substantive meaning of the projects' topics is not the primary focus of this contribution. Rather than delving in the specific topics of these projects, their structure in terms of their theory practice relation is described as well as the emerging problems and the importance of these problems in the further implementation.

\section{Research Questions}

The objective of the following research consists of analyzing the concrete themes with the interweaving of theory and practice concerning teacher-student-relationship. Specifically learning contents and the emerged problems are explored. Firstly, an overview of the three projects is given.

\section{Methodology}

\subsection{The Research Context}

The projects are named as: 1) Encouragement, 2) Social Learning and, 3) Reintegration. The contents of the projects are different, but they have critical similarities. All projects connect school relevant content with concrete practical relevance, which is manifested in the work of the teacher students with students. Without exception, the teacher students take a responsible task, which is previously clearly pointed out and fixed contractually. The teacher students work in a social context: they can compare their work with peers' work (through team teaching and/or reference group). All three projects involve a close-knit and timely supervision by the teacher educators. The teacher students must reflect by writing about their behavior on the basis of the standards of good relationship design and these protocols are subject to the group meetings and individual consultations. In all three projects teacher educators are in close contact with each other and watch themselves and one another to be committed to a supportive interactions style with teacher students. All projects were accompanied scientifically for a longer period and the effects on students already were examined and published, mostly in German Journals and German Reference Books 
(Encouragement: Steins \& Maas, 2014; Social Learning: Steins \& Haep, 2015; Reintegration: Welling, Weber, \& Steins, 2011).

The crucial differences in the three projects are the activities, the size of the group of students and the level of activity (prevention, intervention) and interaction (encouragement: 1 teacher student: 1 adolescent; social learning 2 teacher students: 20 adolescents; reintegration 2 teacher students: 1 adolescent). An overview about the projects is given in Table 1.

\subsubsection{Encouragement}

In cooperation with the German Child Protection Association (Deutscher Kinderschutzbund) and selected cooperation schools, the teacher students, signed an agreement contract with the parents and the adolescent, which endures 12 months. With this contract the teacher students were obliged to take up 40 sessions once a week to meet with the adolescent including the so-called beneficial development activities, each session lasted at least 3 hours. The abstract goal of the concept was to develop a supportive relationship with the adolescent. This goal was concretized by undertaking meaningful activities with the adolescent, tailored to the specific needs of the adolescent. These activities were recorded in writing and reflecting critically with regard to the adolescent-related aims of competencies, previously discussed with a supervisor and the adolescent's class teacher. The effects are already published (Steins, 2012; Steins \& Maas, 2014): Results are predominantly based on class teacher's ratings. After a year these teachers described adolescents as changed to having more motivation, happiness and more openness; also the mathematical and linguistic performance of the

Table 1. Overview: Three theory-practice-projects: Encouragement, social learning and reintegration.

\begin{tabular}{|c|c|c|c|}
\hline Project & Encouragement & Social Learning & Reintegration \\
\hline $\begin{array}{l}\text { Aim for } \\
\text { Teacher Students }\end{array}$ & $\begin{array}{l}\text { building an encouraging } \\
\text { relationship }\end{array}$ & $\begin{array}{l}\text { teaching social learning and being a } \\
\text { social competent model }\end{array}$ & $\begin{array}{l}\text { understanding perspectives of students } \\
\text { with psychological problems }\end{array}$ \\
\hline Operationalization & $\begin{array}{l}\text { create meaningful and } \\
\text { supportive leisure time } \\
\text { activities }\end{array}$ & $\begin{array}{l}\text { preparing and conducting } 14 \text { sections; } \\
\text { keeping professional, supporting } \\
\text { challenging students }\end{array}$ & $\begin{array}{l}\text { supporting students to visit their school } \\
\text { after psychiatry even if school means a } \\
\text { terrible task for them }\end{array}$ \\
\hline $\begin{array}{l}\text { Desired effect } \\
\text { for students }\end{array}$ & $\begin{array}{l}\text { being encouraged } \\
\text { and curious }\end{array}$ & $\begin{array}{l}\text { being motivated to solve social problems } \\
\text { creatively; being motivated to regulate } \\
\text { aggressive impulses }\end{array}$ & staying in school \\
\hline Evaluation of effects & $\begin{array}{l}\text { Pre-Post-Control-Design: } \\
\text { Small to medium effects. } \\
\text { (Steins \& Maas, 2014) }\end{array}$ & $\begin{array}{l}\text { Pre-Post-Control-Follow-Up-Design: } \\
\text { Small effects. } \\
\text { (Steins \& Haep, 2015) }\end{array}$ & $\begin{array}{l}\text { Pre-Post-Control-Follow-Up-Design: } \\
\text { Small effects. } \\
\text { (Welling, Weber, \& Steins, 2011) }\end{array}$ \\
\hline Length & 12 months & 6 to 12 months & 6 weeks to 3 months \\
\hline $\begin{array}{l}\text { Total number } \\
\text { of participants }\end{array}$ & $\begin{array}{l}\text { Students: } 198 \\
\text { Teacher Students: } 198\end{array}$ & $\begin{array}{l}\text { Students: } 540 \\
\text { Teacher Students: } 148\end{array}$ & $\begin{array}{l}\text { Students: } 67 \\
\text { Teacher Students: } 119\end{array}$ \\
\hline
\end{tabular}


adolescents improved significantly compared to how they were before the training period (Steins, 2012) and compared to a control group (Steins \& Maas, 2014). Table 2 gives an overview of the distribution of the theoretical input and practical content, which is very well balanced with this project. Teacher students were involved in a continuous exchange with their supervisor and other teacher students (maximum 8 per group). Students were primary school adolescents (7 9 years). Supervisors continuously discussed with teacher students what it means to be supportive, warm and challenging. Attachment Theory, theories about family and parenthood, education style were central parts of the knowledge that teacher students learnt.

\subsubsection{Social Learning}

For an entire school year, students were given a lesson (90 min each week) on social learning. Courses were taught in smaller groups (about 15 students per group) and by two teacher students. The teacher students were given a basic knowledge of Rational-Emotive-Behavior-Theory and Rational-Emotive-Education and were monitored in the classroom by their teacher educators. They received regular feedback on their interactions regarding their rationality, friendliness, and clarity. Contents of teaching to the students were emotion recognition, emotion regulation, and anger management by means of role-playing, discussion, group work and cognitive exercises. Massive disruption lead to join small groups and teacher students talked with disruptive students by means of a Socratic dialogue until they gained insight and could join the class again. Freire (cited in Bartlett, 2005) had also argued that educators should reject a "banking" model of education which is the teacher's own knowledge deposited in students. Instead, he suggests a "problem-posing" method in which teachers and students learn

Table 2. Actions and theory in the three theory-practice-projects.

\begin{tabular}{|c|c|c|}
\hline Concept & Knowledge & Actions \\
\hline Encouragement & $\begin{array}{l}\text { - } \text { Learning in group } \\
\text { - } 15 \times 2 \text { hours } \\
\text { - } \text { Reflexion Reports } \\
\text { - } 40 \times \\
\text { - } \text { Feedback about reports } \\
\text { - } 40 \times\end{array}$ & $\begin{array}{l}\text { - Meetings with adolescent } \\
\text { - } \text { at least } 3 \text { hours, } 40 \times \\
\text { - } \text { Meetings with teacher of adolescent } \\
\text { - }(2 \times) \\
\text { - } \text { Meetings with parents } \\
\text { - }(\text { at least } 2 \times)\end{array}$ \\
\hline Social Learning & $\begin{array}{l}\text { - } \text { Learning Theory in Group } \\
\text { - } 15 \times \\
\text { - } \text { Learning in Group reflecting } \\
\text { - } 12 \times \\
\text { - } 12 \times 1 \text { Reflection Reports } \\
\text { - } 30 \times \\
\text { - } \text { Feedback of teaching } \\
\text { - } 4-5 \times\end{array}$ & $\begin{array}{l}\text { - Teaching in School } \\
\text { - } 12 \times \\
\text { - } \text { Organizing and conducting class trip } \\
\text { - } 1 \times \\
\text { - Evaluating students } \\
\text { - } 12 \times\end{array}$ \\
\hline Reintegration & $\begin{array}{l}\text { - } \text { Crash lecture } \\
\text { - } 2 \text { days } \\
\text { - } \text { Meetings in groups } \\
\text { - } 3-5 \times \\
\text { - } \text { Reflection Reports } \\
\text { - } 3-12 \times\end{array}$ & $\begin{array}{l}\text { - } \text { Supporting the student } \\
\text { - } 4-12 \times \\
\text { - } \text { Talking with teacher } \\
\text { - } \text { at least } 2 \times \\
\text { - } \text { Talking with therapist } \\
\text { - } \quad \text { at least } 2 \times\end{array}$ \\
\hline
\end{tabular}


together through dialogue. Problem-posing education depends on a dialogical theory of praxis and knowledge and a revised relationship between teacher and student.

At time, Freirean theory also presented dialogue as a pedagogical process, in which teachers and student actively pursue learning through discussion and debate of sociopolitical realities, processes that entail a particular theory of knowledge (cited in Bartlett, 2005).

The effects of the project on students are well evaluated (see Steins \& Haep, 2015). We only found futile small effects regarding problem solving, but additionally found indicators in qualitative data for a preventive function of the project for disruption and disrespectful behavior among students. Table 2 illustrates the theory/practice relation in this concept.

Helpful knowledge for the teacher students with respect to establish and maintain supporting relationships were concepts derived from education style research, and especially Self-Technologies, rational-emotive education (Steins \& Haep, 2015), knowledge from environmental psychology (e.g. caring for personal space; see Steins, Haep, \& Wittrock, 2015).

\subsubsection{Reintegration}

Here, teacher students in teams of two accompanied a student who was dismissed from the psychiatry back to school. The accompanied students all had a problem of school absenteeism for different reasons. The objective for the teacher students was to understand the problems of these students and yet to motivate them to go to school again. To be able to do this, they obtained an introduction to Socratic conversation and school absenteeism, as well as suggestions and theoretical input about supporting relationships. A central part of knowledge was rational-emotive education (Steins \& Haep, 2015). That meant specifically that the students (at least 13 years old) agreed with the teacher student what a support might look like, so that teacher students practiced a wide repertoire of behavior (picking up the student at home, bringing student to the school gate, sitting beside the student in the classroom, accompanying the student back home). Table 2 illustrates the theory/practice relation. The evaluation of the project showed that accompanied students visited school more regularly especially during the hospital stay and in the first two months after being released from psychiatry in comparison with the students who were not (Welling, Weber, \& Steins, 2011).

Initially the scientific focus of all three projects was on the effects of teacher students' efforts on adolescents. As Steins and Maas (2014), Steins and Haep (2015), and Welling et al. (2011) clearly showed, the effects were observable. At this particular time the effect of the teacher students' education which was neglected though their perspectives on the trainings was investigated. As it is noted in Table 2, all teacher students had to write reflexion reports. A reflexion report consists of teacher student's reports about difficulties and success in practice and is an open text. Teacher students sent these texts regularly to their educators and 
received feedback about their reflexions. For the Theory-Practice-Projects Social Learning and Reintegration we randomly chose a sample and reanalysed the reflexion reports considering particularly the themes that hint to important insights by joining these concepts. Fortunately in the project Encouragement we had implemented some questions for the teacher students that they regularly answered after having ended the sponsorship.

\subsection{Samples}

For the present purpose we decided to analyse data from selected samples, because the projects were developed over time and teacher students experienced different social contexts (improved contents, change of supervisors).

Until present, 198 sponsorships were conducted with regard to Encouragement (2003-2016). Thus, for the analysis part we could select teacher students from a total sample of 198 teacher students, participated during the last 13 years. Because this program emerged step by step and the conditions were quite different in the first 5 years, we decided to conduct a group discussion with the current group. The sample consists of 10 teacher students, 14 females, 1 male, with an average age of $M=23.06$ years $(S D=1.20)$.

Social Learning made it possible to collect data from 540 students and 148 teacher students. Likewise as in the Encouragement part, the procedures emerged in the first two years (2009-2015) and self-reports of teacher students were only obligatory in the two last years. For the present study the last group was the one which consisted of 13 teacher students ( 2 males, 11 females) with an average age of $M=23,94(S D=2.08)$.

We accompanied 51 students in Reintegration with the effort of a total sample of 47 teacher students (2009-2011). 10 Teacher students were randomly drawn (4 males and 6 females) with an average age of $M=23.82(S D=2.35)$.

\subsection{Data Base}

\subsubsection{Encouragement}

A group discussion with 10 teacher students was conducted about important experiences. The questions addressed three points of time: beginning, amid the sponsorship and parting. The discussion was transcribed and analyzed for repeating themes.

\subsubsection{Social Learning}

The last batch of 13 teacher students had to write a resume in an open format. This material was coded for repeating themes.

\subsubsection{Reintegration}

In this concept we only have indirect data to explore the learning experiences of the teacher students. They had to write records from every meeting with the adolescents and often were accompanied by the teacher educators. These documents were analyzed for major themes considering learning experiences. 


\subsection{Data Analysis}

The analysis is based on the transcribed and written statements of the students. An exploratory approach was preferred over a hypothesis-based approach. This means that the present study used an exploratory approach in order to obtain and aggregate further knowledge in the domains that are investigated through our research question (Creswell, 2014; Patton, 2002).

\section{Results}

\subsection{Encouragement}

Following, the three phases beginning, midterm and parting are described considering particularly teacher students' experiences.

\subsubsection{Themes Concerning Building a Relation to an Adolescent}

Frequent special features of the adolescent challenged the teacher students. Shyness was such a feature. Teacher students felt helpless when the adolescent was reserved with his/her own opinions about activities. They were afraid that they might decide for activities the adolescent doesn't like and would not recognize. Some adolescents seemed not to be honest to the teacher students and bragged. Teacher students felt angry because the adolescents were lying. Another feature concerned mood swings of adolescents. Teacher students were uncertain how to react when adolescents changed from one mood to another without recognizable reason. Teacher students had to learn about dealing with individual feature which did not fit in their own image of an adolescent. In addition, they had to adapt their image of the perfect adolescent to a real one.

Other challenges are correlated with the adolescent's home. Some parents were unreliable and teacher students had a hard time to organize the meetings and had to struggle for solutions. Other parents suddenly were full of mistrust toward the teacher students. They feared that teacher students could not protect their adolescent in public environments; other parents expected the teacher students doing school homework with their adolescent, and sometimes with adolescent's siblings; some parents worried that teacher students would reveal certain events to youth welfare service; other parents were alarmed recognizing that their adolescent was chosen by their adolescent's teacher and evaluated that as a negative feedback for their education. Further challenges from the adolescent's home were envious siblings who felt missed out if comparing their own activities with the activities teacher students undertook with their brother or sister.

In every case teacher students were challenged to keep tactfully with the policy of the project and simultaneously not to be repellent to parents and siblings.

\subsubsection{Caring for Relationship: Amid the Sponsorship}

Two extreme different challenges occurred repeatedly at this phase of sponsorship. One was monotony in designing the get-togethers. Some adolescents preferred only a small range of activities which did not necessarily fit teacher students' interests. Some of them were worried to explore new possibilities and 
teacher students had to search for compromises and had to motivate their adolescents for stimulation. The other extreme challenge was the adolescent's request for permanent new ideas and activities. Some teacher students perceived a constant pressure to offer new activities. In any case teacher students had to learn a lot of negotiating with an adolescent in order to have satisfying get-togethers for both sides.

Two special topics were associated repeatedly with challenges that evolved after the beginning of the relationship, adolescent's dealing with constraints and perceived ingratitude. Teacher students experienced a wide range of emotions facing adolescents' exceeding constraints. Often teacher students had to deal with adolescents who did not care for traffic rules, did not wash their hands before eating, did not care for rules concerning board games, and did not accept the end of a get-together. Teacher students often were afraid that adolescents would not like them anymore if they insisted on their constraints; but far more seriously was teacher students' uncertainty about the importance of their constraints; they were not always convinced about constraints. Teacher students had to reevaluate their knowledge about reasonable constraints and to learn techniques how to negotiate with adolescents in order to convince them to keep to the constraints.

One important theme is a perceived ingratitude of adolescents. Teacher students gave many examples in which this theme is evident: An adolescent gets two scoops of icecream, and complains because he/she wants to have three scoops; an adolescent perceived a trip in a nature park as boring and wants an expensive trip to an adventure park; an adolescent wants the teacher student to buy expensive gifts. Teacher students, socialized in a materially seducing world, too, are challenged to set reasonable constraints and often feel that they had to offer special things for the adolescent. They learned to differentiate between necessary and not necessary frustrations for the adolescent and to keep to their constraints to a reasonable extent. Some teacher students were angry with their adolescent because they only saw ingratitude. They learned that the adolescent's task is not to be grateful and that the demand for gratefulness is hindering them to lead a responsible and supportive relation with an adolescent.

\subsubsection{End of the Relationship: Parting}

Many teacher students maintained their contact with their adolescents for a long time after ending the formal contract. After all, $42 \%$ of teacher students had the unpleasant feeling that they let their adolescent alone by themselves (Maas \& Steins, 2012). A dominant theme was the imagination of teacher students that the adolescent possibly would miss the inspirations and would suffer from the comparison between the year of sponsorship and time after. Teacher students learned to establish suitable interests in adolescents and to find structures to maintain these interests after parting. Often teacher students could inspire adolescents to join a sports club or get access to a public library. But sometimes they had to part without having success in leaving a structure of inspiration. Finally 
this theme is associated with the recognition that there are clear constraints in pedagogical engagement.

\subsection{Social Learning: Learning Themes}

A repeating theme in the written final reports is "to be friendly and simultaneously orienting and consequent". Most of teacher students admit that it was difficult to stay friendly and consequent and that they often had no fun with this and had a hard time. Repeatedly it was experienced that the fun to teach returned when problems were solved. The main knowledge content also was the experience of self-recognition and self-knowledge: Almost all of the teacher students had some difficulties with emotion regulation. Although they learnt that it is important to avoid negative communication, most of them had anger when students were inattentive, disturbing or provoking. Teacher students worked specifically on their emotion-regulation. Therefore, many of them experienced painful discrepancies between standard and reality. One teacher student concludes: "I am unhappy with my abilities so far"; others state high self-efficacy.

All teacher students appreciated the structure of the concept: to gain feedback and to gain hints how to connect theory with practice. In addition, teacher students enjoyed to work in a team and to plan teaching in a small group very much. A repeating theme during the working in teams was surprising: Teacher students often were surprised that team work was successful and felt supported. Finally, teacher students learned that being prepared for teaching had paid off.

\subsection{Reintegration}

The themes can be categorized into emotional and practical problems concerning home, school and the psychiatric clinic that the students attended and the students themselves.

\subsubsection{Home of Students}

Teacher students often had problems to understand parents' behavior: in some cases parents did not behave responsibly and supported school absenteeism of their adolescents. Teacher students had to learn to stay friendly when confronting this situation and nevertheless had to ask the parents to conform to the contract. They had to learn to regulate their emotions of anger and frustration when parents refused to support. Another topic concerning the students' home was to deal with the parents respectfully which seemed to be bizarre. Teacher students often had a simple image of a suitable couple, or a suitable family in their minds. Learning to accept differences and behaving equally toward them was a central learning theme, including talking about prejudices about single parents, divorced parents, or women with adolescents from different men other than their husbands.

\subsubsection{School}

A major theme is how different teachers' support for the students' reintegration

is. Teacher students had the occasion to observe teachers who blamed students 
for all class problems and also the occasion to observe great support. They were also confronted with prejudices against adolescents with mental problems and their families and could witness great empathy as instructional support. Teacher educators had to discuss usual emotions of anger and even rage toward the teachers who were not only supportive but also attacked these students.

\subsubsection{Clinic}

Teacher students gained a deep insight from the advantages and disadvantages of being a psychiatric patient. They had to regulate their own emotions about therapists they did not perceive as supportive, and about the routines of the students that was often not inspiring. All students visited a clinic school: Here the students are taught during their stay in the clinic in small groups. Quality of teaching in this clinic school is outstanding (Steins, 2008) and without exception teacher students were impressed by the teachers of this school and could observe a constantly friendly and demanding teaching. This was interesting in particular because they could compare student's behavior in the clinic school with the behavior in the real school and thus got an understanding of the relevance of the social context which means the relevance of the relation between teacher and student.

\subsubsection{Students}

Teacher students had to handle many negative events such as dishonest, manipulative, and unreliable students as well as students who showed off. Teacher students had to learn that these behaviors which were expressed by the students were partly expression of a normal development and symptoms of the students' problems. To stay empathic and friendly presuppose that teacher students learned to discriminate students' behavior and student's personality.

\section{Discussion}

Teacher students were challenged by concrete events that tackled the contents of apprenticeship of observation and knowledge which was reinforced by finding solutions for problems and dilemmas. To summarize the most important results: Teacher students often had to learn how to deal with individual features which did not fit in teacher students' image of an adolescent. Thus, they had to adapt their image to a more real one. Teacher students were challenged to keep up with the policy of the project tactfully. With the exception of Social learning they were challenged to be polite to parents and, siblings in the project Encouragement. In any case teacher students had to learn a lot of negotiating with adolescents in order to have satisfying get-togethers for both parties: Teacher students often had to learn techniques to negotiate with adolescents in order to convince them to keep to reasonable constraints. Teacher students worked specifically on their own emotion-regulation. Teacher students often had to doubt their point of view: What kinds of parents are suitable? What is childhood? And how education should be? Learning to accept differences as equal was the main learning theme. Particularly concerning Reintegration, teacher students developed an in- 
sight of being a student with psychic problems.

The discussion starts with the topics of teacher students in Encouragement. Teacher students had the highest responsibility in this concept: They were alone with the adolescent; they decided for the things to do with adolescents alone. Supervisors were usually never present when teacher students met their adolescents. In this concept we can find the most perceived dilemmas by the teacher students. Thus, teacher students' themes can be understood in the light of pedagogical dilemmas or as Schütze, Bräu, Liermann, Prokopp, Speth, and Wiesemann (1996) name them Antinomien which means the Paradox that frames pedagogical engagement (Tillema \& Kremer-Hayton, 2005). As Maas and Steins stated (2012) paradoxical fields of conflicts emerged in the process of building, maintaining and ending a relationship. One of them is closeness and distance: Teacher students learn to get to know the adolescent, and simultaneously set and keep constraints. Another paradox is spontaneity and planning: On the one hand teacher students learned to plan a structured activity but they also learned to adapt to planning at events that were unforeseen and to improvise. Regression and progression denotes a further area of conflict: Teacher students offered to the adolescent a protected frame of reference but also motivated the adolescent to explore new domains. And finally teacher students learned to move between engagement and standoffs. Some teacher students tend to react to the problems with emotional coldness and withdrawal; here the group was a corrective. Other teacher students felt belated because they felt an overwhelming responsibility for the adolescent's future. All in all the themes which emerge in this theory-practiceproject were constantly negotiated in the self-reflection reports, the groups and the individual feedbacks. One whole year, teacher students were learning to deal with these challenging problems.

In a weaker version, similar dilemmas and emotional problems were also stated by teacher students in the other projects. Social Learning as a frame of experience was the most similar to the later classroom situation, but was only weakly associated with the perception of dilemmas and emotional problems in comparison with the other projects. This might be because of diffusion of responsibility, team teaching and the closeness of the supervisors. Possibly, problems are perceived as more annoying if responsibility for the individual decisions is really high and cannot be attributed to other persons. Nevertheless responsibility was high; many teacher students in Social Learning expressed their feelings of responsibility and commitment.

Likewise many of the teacher students' beliefs about how to establish and maintain a supportive relationship could be identified and discussed. Emotional problems were the most salient problems teacher student had: anger and frustration. By Socratic dialogues, teacher educators discussed the situations and associated emotions with teacher students to broaden their perspective on the social side of teaching and supporting adolescents. Knezic, Elbers, Wubbels, and Hajer (2013) identified Socratic dialogues as a technique of interaction, "while raising language awareness and deepening the understanding of dialogical process as 
well as the discussed topics." (p. 504).

Finally teacher students in all three projects had to constantly solve practical problems they had never thought about before. These practical problems were rarely mentioned in the data base of this contribution; nevertheless teacher students never had had an impression of many practical problems without these experiences.

With the exception of few teacher students all agree with the feedback they gave us: Time-consuming project, but an overwhelming learning experience.

\section{Limitations of the Research}

It was never planned to analyze the data with respect to teacher students' themes. Thus, the contexts of the reports are very different. Otherwise a metaanalysis would have been possible. The advantage of this short-coming is that teacher students' impressions are very concrete and informative. Therefore, we avoid "the loss of important evaluation details across time and space..." (Bergstrom \& Taylor, 2006; p. 351). Furthermore, the database is not sufficient. An analysis of all existing reflection reports would be really time-consuming and had to consider the specific changes in the projects. Finally the data are highly subjective data: They exclusively are teacher students' self-reports and it is not possible to say more than that the observed learning effects are subjective impressions.

The focus of the projects was to provide teacher students with knowledge of creating a supportive teacher-student-relationship and guide them in successfully linking theory with practice. We conclude that most of teacher students were able to create such a relationship. There are two kinds of results that support this conclusion. First of all there is indirect support: Our previous research showed positive effects on adolescents' knowledge and competencies. Secondly there are self-report measurements of the teacher students. Furthermore it can be argued that teacher students are forced to handle concrete problems in different situations. The results summarize the many different challenges and learning effects. The solution to these problems is not trivial, but determines the progress in the relationship. Nevertheless the data base gave weak conclusions about the real learning effects. The value of the projects is seen in accentuating relevant contents in teacher education.

\section{Conclusion}

Nevertheless, teacher students would never have these learning opportunities in a simple lecture or seminar. It was and is a repeated feedback of teacher students to the teacher educators that these activities in the projects were overwhelmingly challenging and that they learnt a lot but simultaneously the work was time consuming.

In the beginning of this contribution, we announced that we would like to draw conclusions about the projects' feasibility. The investment of time was not only for teacher students. Teacher educators also had a lot to do with managing 
these projects as well. Time amount was determined by problems with implementation of the projects in the different systems (school, psychiatry), spontaneous counseling of teacher students when unforeseen problems rose, supervision and intensive feedback. It would be very generous to offer these projects as a pure teaching content. But as Irwin and Ryan (2013) note that to make real challenges in learning, the researcher should look for the adequacy of teaching contents.

The opportunity given to teacher students to have a personal and out of school interactions with such students is a great chance for them to learn how to deal with problematic adolescents rather than to simply ignoring them or being aggressive toward them probably the way their own previous teachers behaved inside classrooms.

Maybe it is time to lower the traditional pressure on teachers which forces them to expect only good academic performance of students. Regarding the vital role of a teacher in every student's life the teacher-student relationship must be focused on much more than before since this personal rapport can be very affective not only in the behavior of students but also in their academic performance. Improving the rapport of teacher and students is important because pupils with better, closer and more positive relationships with their teachers attain higher levels of success compared to students who have conflictual relationships with their teachers (Rimm-Kaufman \& Sandilos, 2011).

We can imagine that a student with better interpersonal relationship with the teacher who gets more attention and positive feedback and support from the teacher compared to a student who always is criticized by the teacher performs better. If a student trusts the teacher the probability of more engagement in learning, better behavior and achieving better academic success increases. Positive teacher-student relationships draw students into the process of learning and promote their desire to learn (assuming that the content material of the class is engaging, age-appropriate and well matched to the student's skills) (RimmKaufman \& Sandilos, 2011).

Last but not least, there is another consideration that ends the conclusion: It is rare that learning in order to create a supportive relationship with a student is explicitly taught in teacher education and as far as research can show, supportive relationships are constantly threatened by teachers' stress (Doll, 2013) or by organizational priorities (Malmberg et al., 2010). Projects like the discussed ones strengthen the place of the social dimension in teacher education; they might have only small effects and may increase the work-load for all participants but they set a positive priority. It is mostly desirable that such projects would be supported by each institution that educates teachers.

\section{Outlook}

Many questions are open to understand the processes that enable teacher students to act on an empirically-based basis. On one hand it is necessary to conduct controlled longitudinal section designs comparing the real outcomes of ef- 
forts in order to challenge apprenticeship of learning (via observation of real behavior). On the other hand teacher educators and contexts of teacher education are important variables in the whole picture. It is desirable to understand more the impact of the teacher-educator-teacher student-relationship. Probably the social dimension of the way of learning is a powerful predictor for the future methods of teaching.

\section{Compliance with Ethical Standards}

The authors confirm that they had complied with ethical guidelines.

\section{Conflict of Interest}

The authors have no conflict of interest.

\section{Statement of Authors}

The submitted paper is neither published nor submitted for publication elsewhere.

\section{References}

Algozzine, B., Ysseldyke, J.E., Christenson, S., \& Thurlow, M.L. (1983). A Factor Analysis of Teachers' Intervention Choices for Dealing with Students' Behavior and Learning Problems. The Elementary School Journal, 84, 189-197. https://doi.org/10.1086/461355

Andersen, J. F. (1979). Teacher Immediacy as a Predictor of Teaching Effectiveness. In D. Nimmo (Ed.), Communication Yearbook 3 (pp. 543-559). New Brunswick, NJ: Transaction Books.

Bartlett, L. (2005). Dialogue, Knowledge, and Teacher-Student Relations: Freirean Pedagogy in Theory and Practice. Comparative Education Review, 49, 344-364.

Becker, D. (2013). The Impact of Teachers' Expectations on Students' Educational Opportunities in the Life Course: An Empirical Test of a Subjective Expected Utility Explanation. Rationality and Society, 25, 422-469. https://doi.org/10.1177/1043463113504448

Bergstrom, J. C., \& Taylor, L. O. (2006). Using Meta-Analysis for Benefits Transfer: Theory and Practice. Ecological Economics, 60, 351-360.

Billett, S. (1998). Constructing Vocational Knowledge: Situations and Other Social Sources. Journal of Education and Work, 11, 255-273. https://doi.org/10.1080/1363908980110303

Carli, L. L., \& Eagly, A. H. (2012). Leadership and Gender. In D. V. Day, \& J. Antoakis (Eds), The Nature of Leadership (2nd ed., pp. 437-476). Los Angeles, CA: Sage.

Christophel, D. M. (1990). The Relationship among Teacher Immediacy Behaviors, Student Motivation, and Learning. Communication Education, 39, 323-340. https://doi.org/10.1080/03634529009378813

Comstock, J., Rowell, E., \& Bowers, J. (1995). Food for Thought: Teacher Nonverbal Immediacy, Student Learning, and Curvilinearity. Communication Education, 44, 251-266. https://doi.org/10.1080/03634529509379015

Cornelius-White, J. (2007). Learner-Centered Teacher-Students Relationships Are Effective: A Meta-Analysis. Review of Educational Research, 77, 113-143. https://doi.org/10.3102/003465430298563 
Creswell, J. W. (2014). Educational Research: Planning, Conducting and Evaluating Quantitative and Qualitative Research. Harlow: Pearson.

Den Brok, P., \& Levy, J. (2005). Teacher-Student Relationships in Multicultural Classes: Reviewing the Past, Preparing the Future. International Journal of Educational Research, 43, 72-88.

Dewey, J. (1993). How We Think: A Restatement of the Relation of Reflective Thinking to the Educative Process. Boston: D. C. Heath.

Dobransky, N. D., \&Frymier, A. B. (2004). Developing Teacher-Student Relationships through out of Class Communication. Communication Quarterly, 52, 211-223. https://doi.org/10.1080/01463370409370193

Doll, B. (2013). Enhancing Resilience in Classrooms. In S. Goldstein, \& R. B. Brooks (Eds.), Handbook of Resilience in Children (2nd ed., pp. 399-409). New York, NY: Springer. https://doi.org/10.1007/978-1-4614-3661-4_23

Efihimiou, H. (1995). Teacher Education in Greece: Balancing Theory and Practice. Journal of Modem Greek Studies, 13, 231-241. https://doi.org/10.1353/mgs.2010.0357

Eiss, A. B. (1969). Behavioral Objectives in the Affective Domain. Washington DC: National Science Supervisors Association.

Engeström, Y. (1999). Activity Theory and Individual and Social Transformation. In Y. Engeström, R. Miettinen, \& R. Punamaki (Eds), Perspectives on Activity Theory. Cambridge: Cambridge University Press. https://doi.org/10.1017/cbo9780511812774.003

Engeström, Y. (2001). Expansive Learning at Work: Toward an Activity Theoretical Reconceptualization. Journal of Education and Work, 14, 133-156. https://doi.org/10.1080/13639080020028747

Evertson, C. M., \& Weinstein, C. S. (2006). Classroom Management as a Field of Inquiry. In C. M. Evertson, \& C. S. Weinstein (Eds.), Handbook of Classroom Management. Research, Practice, and Contemporary Issues (pp. 3-16). Mahwah, NJ: Lawrence Erlbaum Associates.

Forzani, F. M. (2014). Understanding "Core Practices" and "Practice-Based" Teacher Education: Learning from the Past. Journal of Teacher Education, 65, 357-368. https://doi.org/10.1177/0022487114533800

Freire, P. (1973). Education for Critical Consciousness. New York, NY: Continuum.

Fritz, S., Karin, B., Hildegard, L., Karl, P., Martin, S., \& Jutta, W. (1996). Consideration about Paradox of Teachers' Action in Dimensions of School Organization. In W. Helsper, H.-H. Krüger, \& H. Wenzel (Eds.), School and Society in Change, Theoretical and International Perspectives (pp. 333-377, Vol. 1). Weinheim: Deutscher Studienverlag.

Garcia, J. A., \& Lewis, T. E. (2014). Phenomenological Teacher Education. Curriculum Inquiry, 44, 141-168. https://doi.org/10.1111/curi.12042

Gruber, H., Law, L., Mandl, H., \&Renkl, A. (1995). Situated Learning and Transfer. In P. Reimann, \& H. Spada (Eds), Learning in Humans and Machines: Towards an Interdisciplinary Learning Science. Oxford: Pergamon.

Hamre, B. K., \& Pianta, R. C. (2001). Early Teacher-Adolescent Relationships and the Trajectory of Adolescents' School Outcomes through Eighth Grade. Adolescent Development, 72, 625-638.

Hamre, B. K., \& Pianta, R. C. (2005). Can Instructional and Emotional Support in the First-Grade Classroom Make a Difference for Adolescents at Risk of School Failure? Adolescent Development, 76, 949-967.

Hattie, J. (2009). Visible Learning. London: Routledge.

Hawthorne, J., \& Stanley, J. (2008). Knowledge and Action. The Journal of Philosophy, 
105, 571-590. https://doi.org/10.5840/jphil20081051022

Hebert, C. (2015). Knowing and/or Experiencing: A Critical Examination of the Reflective Model of John Dewey and Donald Schön. Reflective Practice, 16, 361-371. https://doi.org/10.1080/14623943.2015.1023281

Hoeppner, C., von Keyserlingk, L., Koerndle, H., \& Proske, A. (2015). A Bridge between Theory and Practice in Teacher Education-Microteaching as a Practical Teaching Concept. Report Psychologie, 40, 152-162.

Irwin, R. L., \& Ryan, T. D. (2013). Get Real: Using Engagement with Practice to Advance Theory Transfer and Production. Sport Management Review, 16, 12-16.

Janssen, F., Westbroek, H., \& Doyle, W. (2014). The Practical Turn in Teacher Education: Designing a Preparation Sequence for Core Practice Frames. Journal of Teacher Education, 65, 195-206. https://doi.org/10.1177/0022487113518584

Knezic, D., Elbers, E., Wubbels, T., \& Hajer, M. (2013). Teachers' Education in Socratic Dialogue: Some Effects on Teacher-Learner Interaction. The Modern Language Journal, 97, 490-505. https://doi.org/10.1111/j.1540-4781.2013.12014.x

Larrivee, B. (2006). The Convergence of Reflective Practice and Effective Classroom Management.

Lewin, K. M., \& Stuart, J. M. (2003). Insights into the Policy and Practice of Teacher Education in Low-Income Countries: The Multi-Site Teacher Education Research Project. British Education, 29, 691-707. https://doi.org/10.1080/0141192032000133703

Lewin, K., \& Grabbe, P. (1945). Conduct, Knowledge, and Acceptance of New Values. Journal of Social Issues, 1, 53-64. https://doi.org/10.1111/j.1540-4560.1945.tb02694.x

Liew, J., Chen, Q., \& Hughes, J. N. (2010). Adolescent Effortful Control, Teacher-Student-Relationships, and Achievement in Academically At-Risk Adolescents: Additive and Interactive Effects. Early Adolescenthood Research Quarterly, 25, 51-64.

Loewenberg Ball, D., \& Forzani, F. M. (2009). The Work of Teaching and the Challenge for Teacher Education. Journal of Teacher Education, 60, 497-511.

https://doi.org/10.1177/0022487109348479

Lortie, D. (1975). School Teacher: A Sociological Study. London: University of Chicago Press.

Malmberg, L.-E., Hagger, H., Burn, K., Mutton, T., \& Colls, H. (2010). Observed Classroom Quality during Teacher Education and Two Years of Professional Practice. Journal of Educational Psychology, 102, 916-932.

https://doi.org/10.1037/a0020920

McAllister, G. (1999). Urban Teachers' Beliefs about Culture and the Relationship of Those Beliefs to Their Practice. Dissertation Abstracts International, 60-05A, 1428.

Meissel, K., \& Rubie-Davies, C. M. (2016). Cultural Invariance of Goal Orientation and Self-Efficacy in New Zealand: Relations with Achievement. British Journal of Educational Psychology, 86, 92-111. https://doi.org/10.1111/bjep.12103

Morris, V. G., \& Morris, C. L. (2002). Caring-The Missing C in Teacher Education. Lessons Learned from a Segregated African American School. Journal of Teacher Education, 53, 120-122. https://doi.org/10.1177/0022487102053002011

Muller, C. (2001). The Role of Caring in the Teacher-Student Relationship for at Risk Students. Social Inquiry, 71, 241-255. https://doi.org/10.1111/j.1475-682X.2001.tb01110.x

Murray, C., \& Pianta, R. C. (2007). The Importance of Teacher-Student Relationships for Adolescents with High Incidence Disabilities. Theory into Practice, 46, 105-112. https://doi.org/10.1080/00405840701232943

National Research Council and the Institute for Medicine (2004). Engaging Schools: Fos- 
tering High School Students' Motivation to Learn. Washington DC: The National Academies Press.

Patton, M. Q. (2002). Qualitative Research and Evaluation Methods (3rd ed.). Thousand Oaks, CA: SAGE.

Peterson, E. R., Rubie-Davies, C., \& Sibley, C. (2016). Teachers' Explicit Expectations and Implicit Prejudiced Attitudes to Educational Achievement: Relations with Student Achievement and the Ethnic Achievement Gap. Learning and Instruction, 42, 123-140.

Philpott, C. (2006) Transfer of Learning between Higher Education Institution and SchoolBased Components of PGCE Courses of Initial Teacher Education. Journal of Vocational Education \& Training, 58, 283-302. https://doi.org/10.1080/13636820600955286

Pianta, R. C. (1999). Enhancing Relationships between Children and Teachers. Washington DC: American Psychological Association. https://doi.org/10.1037/10314-000

Pianta, R. C., Hamre, B., \& Stuhlman, M. (2003). Relationships between Teachers and Children. In W. M. Reynolds, \& G. E. Miller (Eds.), Handbook of Child Psychology: Educational Psychology (Vol. 7, pp. 199-234). Hoboken, NJ: John Wiley \& Sons. https://doi.org/10.1002/0471264385.wei0710

Reddy, R., Rhodes, J. E., \& Mulhall, P. (2003). The Influence of Teacher Support on Student Adjustment in the Middle School Years: A Latent Growth Curve Study. Development and Psychopathology, 15, 119-138. https://doi.org/10.1017/S0954579403000075

Reyes, J. A., Elias, M. J., Parker, S. I., \& Rosenblatt, J. L. (2013). Promoting Educational Equity in Disadvantaged Youth: The Role of Resilience and Social-Emotional Learning. In S. Goldstein, \& R. B. Brooks (Eds.), Handbook of Resilience in Adolescents (2nd ed., pp. 349-370). New York, NY: Springer. https://doi.org/10.1007/978-1-4614-3661-4_20

Rimm-Kaufman, S., \& Sandolis, L. (2011). Improving Students' Relationships with Teachers to Provide Essential Supports for Learning. http://www.apa.org/education/K12/relationships.aspx

Rousmaniere, K. (1994). Losing Patience and Staying Professional: Women Teachers and the Problem of Classroom Discipline in New York City Schools in the 1920s. History of Education Quarterly, 34, 49-68. https://doi.org/10.2307/369228

Rowell, J. A., Pope, S., \& Sherman, B. F. (1992). Relating Theory to Practice in Teacher Education. Journal of Education for Teaching, 18, 159-172. https://doi.org/10.1080/0260747920180205

Rushton, S. P. (2000). Student Teacher efficacy in Inner-City Schools. The Urban Review, 32, 365-383. https://doi.org/10.1023/A:1026459809392

Schön, D. (1983). The Reflective Practitioner. London: Jossey-Bass.

Shechtman, Z., \& Leichtentritt, J. (2004). Affective Teaching: A Method to Enhance Classroom Management. European Journal of Teacher Education, 27, 323-333. https://doi.org/10.1080/0261976042000290822

Skiba, R. J., \& Knesting, K. (2001). Zero Tolerance, Zero Evidence: An Analysis of School Disciplinary Practice. In R. J. Skiba, \& G. G. Noam (Eds.), New Directions for Youth Development: Theory, Practice, Research (pp. 11-43). San Francisco, CA: Jossey-Bass. https://doi.org/10.1002/yd.23320019204

Sleeter, C. (2008). Equity, Democracy, and Neoliberal Assaults on Teacher Education. Teaching and Teacher Education, 24, 1947-1957.

Steins, G. (2000). Motivation in Person Perception: Role of Other's Perspective. Journal of Social Psychology, 140, 692-709. https://doi.org/10.1080/00224540009600510

Steins, G. (2008). School in Spite of Disease. Evaluation of Teaching Adolescents with Diseases and Implications for Schools. Berlin: Pabst Science Publishers.

Steins, G. (2012). Development by Sponsorships: Are There Effects? In M. Maas, \& G. 
Steins (Eds.), Time for Children-Experiences and Effects of Sponsorships (pp. 30-46). Berlin: Pabst Science Publishers.

Steins, G., \& Maas, M. (2014). Encouragement of Social Competencies-Sponsorships from an Attachment Perspective. In C. Rohlfs, M. Harring, \& C. Palentien (Eds.), Competence-Education. Social, Emotional and Communicative Competencies of Adolescents (2nd ed., pp. 363-374). Wiesbaden: Verlag für Sozialwissen-Schaften.

Steins, G., \&Haep, A. (2015). Social Learning and Rational-Emotive Education: An Exploratory Investigation of Students' Perceptions. Psychology, 6, 1096-1107. https://doi.org/10.4236/psych.2015.69107

Steins, G., Haep, A., \& Wittrock, K. (2015). Technology of the Self and Classroom Management-A Systematic Approach for Teacher Students. Creative Education, 6, 2090-2104. https://doi.org/10.4236/ce.2015.619213

Steins, G., Wittrock, K., \& Haep, A. (2015). Contents of Classroom Management: What Is Necessary, What Is Possible, How Is It Done at School? Creative Education, 6, 20452062. https://doi.org/10.4236/ce.2015.619210

Steins, G., Wittrock, K., \& Haep, A. (2016). The Effects of Classroom Management Education on Handling a Class Disruption among Teacher Students. Creative Education, 7, 2403-2422. https://doi.org/10.4236/ce.2016.716231

Tillema, H., \& Kremer-Hayon, L. (2005). Facing Dilemmas: Teacher-Educators' Ways of Constructing a Pedagogy of Teacher Education. Teaching in Higher Education, 10, 203-217. https://doi.org/10.1080/1356251042000337954

Warren, C., \& Hotchkins, B. K. (2015). Teacher Education and the Enduring Significance of False Empathy. The Urban Review, 47, 266-292.

https://doi.org/10.1007/s11256-014-0292-7

Weinstein, C. S., Tomlinson-Clarke, S., \& Curran, M. (2004). Toward a Conception of Culturally Responsive Classroom Management. Journal of Teacher Education, 55, 2538. https://doi.org/10.1177/0022487103259812

Welling, V., Weber, P., \& Steins, G. (2011). A Concept for Reintegration from Psychiatry into School for Adolescents with School Problems and School Absenteeism. Zeitschriftfür Heilpädagogik, 62, 502-510.

Woolfolk Hoy, A., \& Weinstein, C. S. (2006). Student and Teacher Perspectives on Classroom Management. In C. M. Evertson, \& C. S. Weinstein (Eds.), Handbook of Classroom Management. Research, Practice, and Contemporary Issues (pp. 181-219). Mahwah, NJ: Lawrence Erlbaum Associates.

Zeichner, K. M. (1993). Traditions of Practice in U.S. Preservice Teacher Education Programs. Teaching \& Teacher Education, 9, 1-13. 
Submit or recommend next manuscript to SCIRP and we will provide best service for you:

Accepting pre-submission inquiries through Email, Facebook, LinkedIn, Twitter, etc. A wide selection of journals (inclusive of 9 subjects, more than 200 journals)

Providing 24-hour high-quality service

User-friendly online submission system

Fair and swift peer-review system

Efficient typesetting and proofreading procedure

Display of the result of downloads and visits, as well as the number of cited articles Maximum dissemination of your research work

Submit your manuscript at: http://papersubmission.scirp.org/

Or contact psych@scirp.org 